\title{
OVERLOOKING THE RIVER STOUR
}

THE swallows flew in the curves of an eight

Above the river-gleam

In the wet June's last beam:

Like little crossbows animate

The swallows flew in the curves of an eight

Above the river-gleam.

Planing up shavings of crystal spray

A moor-hen darted out

From the bank thereabout,

And through the stream-shine ripped his way;

Planing up shavings of crystal spray

A moor-hen darted out.

Closed were the kingcups; and the mead

Dripped in monotonous green,

Though the day's morning sheen

Had shown it golden and honeybee'd;

Closed were the kingcups; and the mead

Dripped in monotonous green

And never I turned my head, alack,

While these things met my gaze

Through the pane's drop-drenched glaze,

To see the more behind my back. ...

$O$ never I turned, but let, alack,

These less things hold my gaze! 